\title{
Mobilising internally generated funds to finance development projects in Ghana's Northern Region
}

\author{
Commonwealth Journal of Local Governance \\ Issue 18: December 2015 \\ http://epress.lib.uts.edu.au/ojs/index.php/cjlg
}

\author{
Felix Puopiel \\ Institute of Local Government Studies \\ Northern Region \\ Ghana
}

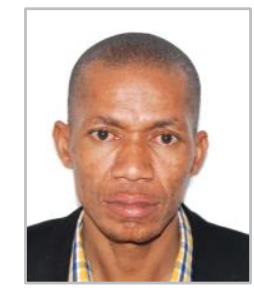

\section{Musah Chimsi}

Saboba District Assembly

Northern Region

Ghana

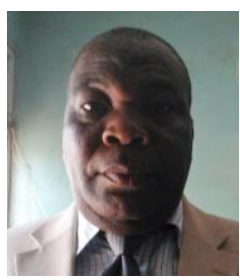

\begin{abstract}
This paper assesses the effectiveness of Metropolitan, Municipal and District Assemblies (MMDAs) in Ghana's Northern Region in mobilising internally generated funds (IGF) to finance development projects. The study gathered both primary and secondary data from three MMDAs: Tamale Metropolitan Assembly, Yendi Municipal Assembly and Saboba District Assembly. It employed a multi-stage sampling technique of questionnaires, interviews, focus groups and key informant interviews to collect data from respondents and obtain a snapshot of their situation in the 2013 fiscal year. It established that fines, property rates, licences, annual rates, investment income, permits, sales of tender documents, and business taxes were potential sources of revenue for the assemblies. Also, the study identified a range of strategies employed by assemblies to raise revenue: engagement of revenue collectors, use of a mobile revenue taskforce, registration of businesses, visits to markets and business centres, commission payments for revenue collectors, security checkpoints, incentivisation of revenue collectors, establishment of revenue collection points, and rotation of revenue collectors. Nevertheless, the study found that the MMDAs studied could not meet their IGF revenue targets for the 2013 fiscal year, with all three falling below 50\%. This poor performance was attributed to: inadequate logistics to support effective IGF mobilisation; under-declaring of revenues; not enough revenue collectors; poor supervision and monitoring; poor compliance by ratepayers; corruption; political interference; inadequate knowledge and skills among revenue collectors; poor service delivery by the assemblies; ineffective collaboration; and lack of revenue data.
\end{abstract}

(C) 2015 Felix Puopiel and Musah Chimsi. This is an Open Access article distributed under the terms of the Creative Commons Attribution 4.0 Unported (CC BY 4.0) License (https://creativecommons.org/licenses/by/4.0/), allowing third parties to copy and redistribute the material in any medium or format and to remix, transform, and build upon the material for any purpose, even commercially, provided the original work is properly cited and states its license.

Citation: Commonwealth Journal of Local Governance 2015, 18: 4848, - http://dx.doi.org/10.5130/cjlg.v0i18.4848 


\section{Introduction}

The local government system in Ghana is premised on the assumptions that development must respond to people's problems and represent objectives and priorities; and that responsibility for development is shared by central government, local governments, parastatals, non-governmental organisations (NGOs) and the people as the ultimate beneficiaries of development. District assembly financing resources are thus essential to enable local governments to translate their powers and competences into development activities.

The financial provisions for Ghana's local government system are contained in Section 27, Parts IV and VIII of the Local Government Law 1988; in the Provisional National Defence Council (PNDC) Law 207; and in Articles 245 and 252 of the 1992 Constitution of the Republic of Ghana (Government of Ghana 1988, 1992, 1993 and 2003). In this regard, revenues for decentralised government agencies (ie Metropolitan, Municipal and District Assemblies (MMDAs) are broadly classified as internally generated funds (IGF), District Development Facility (DDF) grants and central government transfers (grants-in-aid and ceded revenue). The introduction of the District Assemblies Common Fund (DACF), under which $7.5 \%$ of the national budget is allocated to districts, has further strengthened the framework of local government in Ghana.

To strengthen the financing base of MMDAs, the Local Government Act 1993 (No. 462) allows MMDAs to raise revenue locally for the purpose of undertaking independent development projects without needing to rely on central government support or other external sources of funding. However, research has shown that over the years MMDAs have not been able to do this effectively. Empirical studies have shown that more than $60 \%$ of revenues for MMDAs have come from central government and partner sources. Osei-Akoto et al. (2007) found that between 1994 and 2004 IGF constituted an average of just $31.8 \%$ of MMDA revenue, whereas nearly $60 \%$ came from other sources (eg grants from development partners, the DACF and the DDF). Furthermore, in 2006 Ghana's Ministry of Local Government, Rural Development and Environment indicated that IGF for MMDAs stood at $18 \%$ of revenues, compared to central government grants at $82 \%$ (cited in Appiah-Agyekum et al. 2013). This implies a wide gap between revenues generated internally and those coming from external sources.

MMDAs' inability to generate substantial internal revenues for development projects is a national problem, but it appears to be particularly acute in the Northern Region. IGF statistics for the past five years in the Region show consistent budget deficits due to inadequate generation of IGF by MMDAs. The average revenue performance of the Northern Region on IGF stood at $74 \%$ of budgeted performance in 2008 , dropping to $62 \%$ in the 2009 fiscal year, then rising to $83 \%$ in 2010 and 
maintaining that level in 2011. However, average IGF performances in the Region then dropped to $76.15 \%$ and $67.01 \%$ of budgeted revenue during the 2012 and 2013 fiscal years (Northern Region Coordinating Council 2008/13). The question thus remains how adequate the revenues mobilised are to finance development projects?

Thus, most MMDAs in the Region rely heavily on central government transfers (notably the DACF) and other external sources to finance their development projects. But this reliance typically delays the implementation of their Medium Term Development Plans (MTDPs). Funding often fails to meet budgeted requirements, which means that development projects are not completed on schedule or often left uncompleted. It is thus crucial for MMDAs to mobilise locally generated funds, in order to implement development plans without needing to rely on central government and development partners. In this light, this study seeks to explore why MMDAs in the Northern Region have difficulty in meeting IGF targets.

\section{Objectives}

The paper has four main objectives:

i) to assess the sources of IGF for MMDAs;

ii) to document the strategies employed by assemblies in generating revenue locally;

iii) to analyse the effectiveness of these strategies; and

iv) to examine the challenges encountered by the assemblies in mobilising the funds they need.

\section{Literature review}

This section discusses relevant literature on IGF mobilisation, including conceptual and empirical frameworks.

\section{Conceptual framework}

The concept of IGF is defined variously by authors. According to Kazentet (2011) an internally generated fund (IGF) consists of funds collected exclusively by or for sub-national governments. Operationally, IGF is revenue that is directly generated by district assemblies (DAs) within their areas of jurisdiction, and as such is the only revenue over which DAs have absolute control (how and where it is spent). The sources of IGF as spelt out by Lutaya and West (2009) and Adu-Gyamfi (2014) are illustrated in Table 1. 
Table 1: Sources of IGF

\begin{tabular}{|c|c|}
\hline & Source of IGF \\
\hline 1 & Fees \\
\hline 2 & Fines \\
\hline 3 & Property rates \\
\hline 4 & Licences \\
\hline 5 & Rents \\
\hline 6 & Annual rates \\
\hline 7 & Investment income \\
\hline 8 & $\begin{array}{l}\text { Possession tax (A tax levied on movable property, for example cattle ranch, motor bicycle, } \\
\text { tractors, commercial vehicles, etc.) }\end{array}$ \\
\hline
\end{tabular}

Source: Lutaya and West 2009; Adu-Gyamfi 2014

Figure 1 below presents a conceptual view of effective mobilisation of IGF by MMDAs. The diagram shows that the effectiveness of mobilisation depends on which strategies are adopted and how efficient they are, which itself depends on the quality and capacity of MMDA staff, ie: the skills, knowledge and experience of permanent, casual, or volunteer staff engaged in IG collection and administration. However, there are also other factors that affect effective mobilisation of IGF, such as: the extent to which the general public is aware of the need to pay and co-operate in paying fees, taxes, or rates, and the extent of corruption associated with IGF structures and mobilisation.

Figure 1: Key variables in MMDA IGF mobilisation

Source: Authors 2014

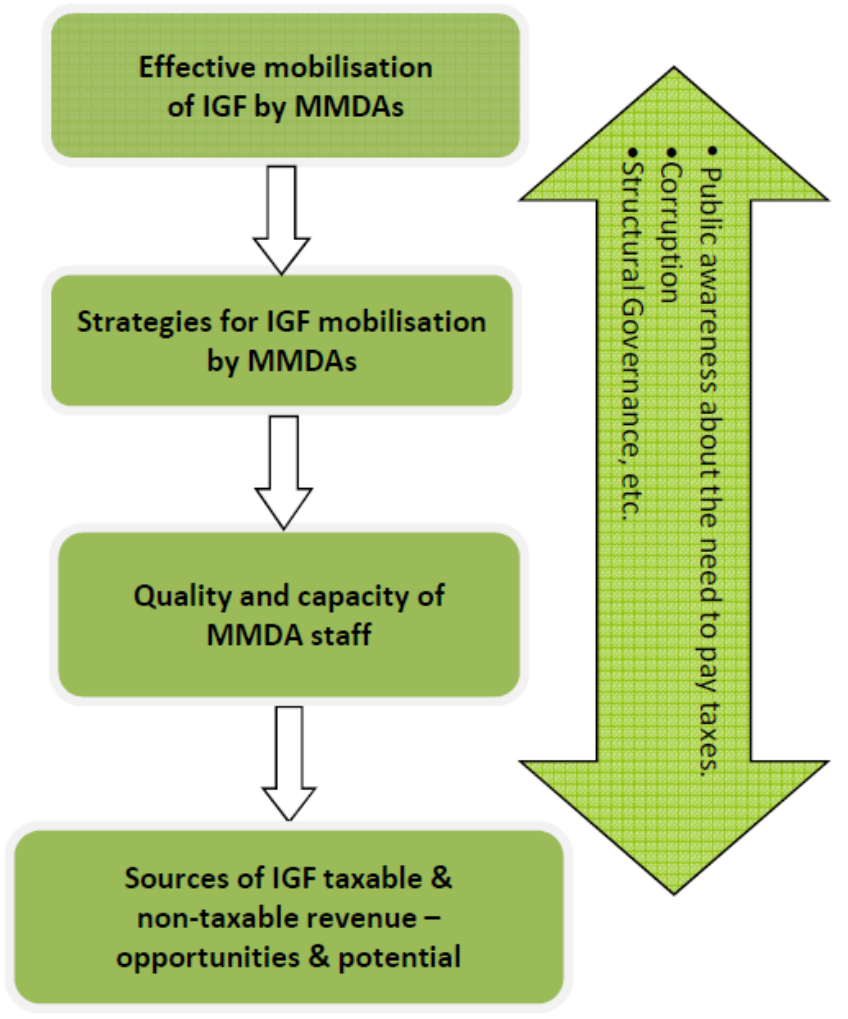




\section{Empirical framework}

Various studies have been conducted on the success of local authorities in Ghana (ie MMDAs) in mobilising IGF to undertake development projects. One such study is that of Abura-AsebuKwamankese District Assembly in the 2011/12 fiscal year by Dick-Sagoe (2012). He established that the assembly did not meet its revenue targets partly due to a lack of the required staffing and skills, and partly due to a lack of innovation on the part of the assembly. This situation was not unique to Abura-Asebu-Kwamankese District Assembly, but was also found in Kumasi Metropolitan Assembly, which had been expected to do well in terms of IGF generation because they have a large revenue pool (Dick-Sagoe 2012).

In another study, Alupungu et al. (2012) found that IGF for the Kumasi Metropolitan Assembly in the 2011/12 fiscal year constituted just $12 \%$ of total revenue, implying an even wider gap between IGF and external sources for all MMDAs. This abysmal performance was attributed to citizens' lack of awareness of the need to pay taxes to the assembly, as well as to inadequate logistics and lack of motivation by revenue collectors.

Agyapong (2012), in a study of Kumasi Metropolitan Assembly, further found that revenues mobilised could not finance the infrastructure needed, finding that the shortfall of revenue was mainly due to corruption amongst revenue collectors, officers and assemblymen in the various Sub-Metro Districts. The study concluded that Kumasi was not harnessing fiscal decentralisation enough to empower itself under the Local Government Act 1993, with the result that the assembly had not developed new and sustainable strategies to improve its performance in revenue mobilisation. The assembly, like many local authorities in Ghana, was over-reliant on the DACF to meet its capital expenditure, while much of its IGF went on administrative costs.

The difficulty local authorities face in raising local revenue to undertake development projects is not peculiar to Ghana. Buettner and Wildasin (2006) found that in the United States an increase in external grants to local governments led to reduced own-revenue generation.

In Nigeria, a study by Chukwuma in 2010 noted that the most crucial challenge to local authorities in Nigeria in mobilising IGF was their inability to raise, retain and manage revenues. This was attributed to instability within the political system, the absence of structured institutions for raising IGF, and the unsustainability of identified sources of IGF. Nevertheless, there have been a few successes in Nigeria. Adesoji and Chike (2013) established that IGF had contributed significantly to the infrastructure development in Lagos State. The main strategies employed in mobilising IGF by Lagos State were enforcement by penalising non-payers, training of tax personnel, and awareness-raising among the general public - the potential taxpayers - about their responsibility to pay. 
In conclusion, the literature suggests that IGF mobilisation is a problem for local authorities in developing countries generally, and Ghana is no exception. Most assemblies in Ghana are over-reliant on central government transfers (notably the DACF) and external sources to finance development projects. This study now turns to the question of why MMDAs are unable to mobilise the needed revenue.

\section{Study area and methodology}

This section briefly describes the study area and the methodology employed in collecting data.

\section{The study area}

The Northern Region is an administrative region of Ghana, with Tamale as its capital. It is the largest Region in Ghana in terms of land area, at about $70,384 \mathrm{~km}^{2}$ ( $29 \%$ of the country's total land area).

\section{Figure 2: Case study MMDAs}

Source: Authors 2014

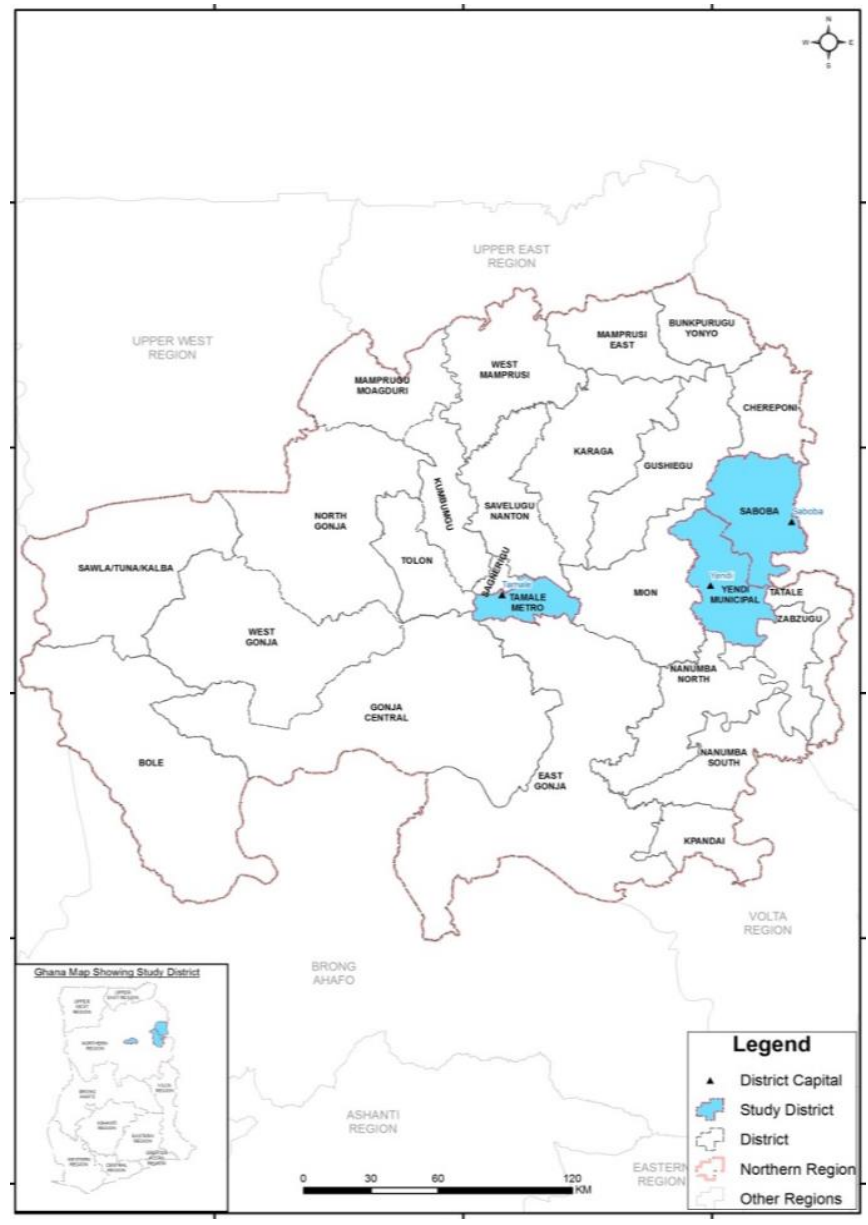

The Northern Region lies completely in the savannah belt of Ghana, and shares borders with Togo to the east, Côte d'Ivoire to the west, Brong Ahafo and Volta Regions to the south and Upper East and Upper West Regions to the north (Yussif 2012). It has 24 MMDAs: one Metropolitan Assembly, two Municipalities and 21 districts. The case study MMDAs: Tamale Metropolitan Assembly, Yendi Municipal Assembly and Saboba District Assembly (Figure 2), were chosen as representing a diversity of MMDAs since the study targeted a metropolis, municipal and district. This also enabled the study to look at potential variations in IGF mobilisation (sources, strategies and challenges) between metropolitan, municipal and district assemblies. 


\section{Research design}

As this paper aims to assess the effectiveness of IGF mobilisation by MMDAs, a research design was adopted that is both descriptive and cross-sectional, using qualitative and quantitative data to yield verbal and numerical pictures, and uncover information which can stimulate new explanations to contradict or support prior beliefs about a subject (Neuman, 1997; Sarantakos, 2005). The combination of descriptive and cross-sectional elements aimed to expose any differences of views and dynamics between the various study populations. Collection of both primary and secondary data enabled the researchers to identify and describe the effectiveness of IGF mobilisation by MMDAs in Tamale Metropolis, Yendi Municipality and Saboba District, giving a snapshot of the situation as it existed when the study was conducted.

\section{Sources of data}

Primary data was gathered from administrative staff, IGF collectors and tax or ratepayers within the selected MMDAs. Secondary data was sourced from MMDA reports, mainly annual reports on IGF targets and mobilisation activities. The secondary sources helped to identify relevant information on the conceptual issues, and to identify research gaps to guide the primary data needed.

\section{Study population and sample size}

The study captured three categories of respondents, all of whom had day-to-day roles in IGF mobilisation within the selected MMDAs (Table 2). The total sample size for the study was 279, with the breakdown of respondents in Table 3 .

Table 2: Respondent types

\begin{tabular}{|c|l|}
\hline & Category of respondents \\
\hline 1 & IGF payers (eg business owners, shop owners, owners of properties such as buildings) \\
\hline 2 & IGF collectors \\
\hline 3 & $\begin{array}{l}\text { Core administrative staff (eg co-ordinating directors, finance officers, planning officers, accounts } \\
\text { clerks, area council chairpersons) }\end{array}$ \\
\hline
\end{tabular}

Source: Authors 2014

Table 3: Study population and sample size

\begin{tabular}{|l|c|c|c|c|}
\hline MMDAs & IFG payers & IGF collectors & Staff of MMDAs & Total \\
\hline Tamale Metropolis & 55 & 69 & 21 & $\mathbf{1 4 5}$ \\
\hline Yendi Municipality & 45 & 27 & 11 & $\mathbf{8 3}$ \\
\hline Saboba District & 30 & 12 & 9 & $\mathbf{5 1}$ \\
\hline Total & $\mathbf{1 3 0}$ & $\mathbf{1 0 8}$ & $\mathbf{4 1}$ & $\mathbf{2 7 9}$ \\
\hline
\end{tabular}

Source: Authors 2014

Table 3 shows that the sample size for IGF payers was 130; that of IGF collectors was 108; and that of administrative staff was 41 . The total sample size for Tamale Metropolis was 145; for Yendi Municipality 83; and for Saboba District 51. 


\section{Data collection tools and techniques}

The researcher used a structured questionnaire and a series of guided focus groups to collect primary data from the three categories of respondents. First, the questionnaire was pre-tested in two other Northern Region districts: Savelugu-Nanton Municipal Assembly and Kumbungu District Assembly. These pilots were analysed and tested for reliability using Cronbach's 'alpha' test. The test value was 0.832, indicating a good level of internal consistency (over 80\%), suggesting that a similar level of reliability might be achieved in another setting.

The questionnaire was then used to collect data from revenue collectors and tax and rate payers, as well as data on the strategies employed by assemblies in mobilising IGF, the effectiveness of these strategies, and the challenges faced by MMDAs in IGF mobilisation. Respondents were engaged in face-to-face interviews and answers given on the structured questionnaire.

Focus groups were also used to gather in-depth data from core administrative MMDA staff with relevant knowledge on sources of IGF, strategies for IGF mobilisation, effectiveness of these strategies and their challenges. Issues raised in the questionnaire interviews were also further clarified through focus group discussions. Three focus groups were held, one for each assembly, with seven participants in each, ie 21 staff in total. The groups were facilitated by the study authors to ensure discussion remained on topic.

\section{Sampling methods}

A multi-stage sampling technique was employed to select respondents from the three research categories.

First, a stratified sampling technique was used to identify zonal, town or area councils within each district. This enabled respondents to be fairly represented across the various area, zonal, town and urban councils in the selected MMDAs. Secondly, a purposive sampling technique was used to select zonal, town and area councils with revenue-raising potential - eg availability of businesses, rateable properties etc.

Thirdly, a random sampling technique was used to select IGF collector respondents. This was to ensure that each IGF collector was given an equal and non-zero chance of being selected. Once the list of collectors was compiled and names serially arranged, numbers were written on pieces of paper up to the number of IGF collectors per area/zonal/town/urban council, placed in a black polythene bag and mixed. The researchers then dipped their hands alternately into the bag to pick out the required number of IGF collectors to be sampled per area/zonal/town/urban council. The selection was done 
without replacement - ie each time a number was selected it was not put back into the bag. All numbers selected were then matched to their corresponding IGF collector name on the list.

A 'convenience' sampling technique was used to select respondents with obligations to pay IGF, since no detailed list of this category of respondents was available. Finally, a purposive sampling technique was used to select assembly administrative staff for inclusion.

\section{Results and discussion}

This section analyses and discusses the field data collected, according to the thematic areas addressed in the paper. These are: sources of IGF, collection strategies and their effectiveness, and collection challenges confronting the district assemblies under study.

\section{Sources of IGF}

The sources of IGF identified by the field data were similar to those spelt out in the Local Government Act 1993 and those found by earlier researchers (Lutaya and West 2009; Kazentet 2011; Agyapong 2012; Alupungu et al. 2012; and Adu-Gyamfi 2014) (see Table 1). This suggests a potentially wide revenue pool for MMDAs in the region, since they are entitled to collect revenue from multiple sources.

\section{Strategies for mobilising IGF}

The field data showed that all the district assemblies had strategies for mobilising revenue (Table 4).

Table 4: Strategies for mobilising IGF

\begin{tabular}{|c|c|c|}
\hline & Assembly & IGF mobilisation strategy \\
\hline 1. & Tamale Metropolis & $\begin{array}{ll} & \text { Use of mobile taskforce } \\
\text { - } & \text { Sensitisation of the public to IGF collection through radio advertising } \\
\text { - } & \text { Engagement of IGF collection agency to support permanent staff } \\
\text { - } & \text { Use of lorry stations } \\
\text { - } & \text { Registration of business entities } \\
\text { - } & \text { Intenitoring of and visits to businesses } \\
\text { - } & \quad \text { Training and incentivisation of revenue collectors } \\
\text { - } & \text { Provision of adequate logistics for revenue mobilisation }\end{array}$ \\
\hline 2. & Yendi Municipality & $\begin{array}{l}\text { - Use of commission targets for revenue collectors } \\
\text { - } \quad \text { Use of mobile taskforce } \\
\text { - } \quad \text { Use of security barriers for IGF collection } \\
\text { - Use of both permanent and casual revenue collectors }\end{array}$ \\
\hline 3. & Saboba District & $\begin{array}{ll} & \text { Incentivisation of revenue collectors } \\
\text { - } & \text { Use of IGF mobilising taskforce } \\
\text { - } & \text { Erection of revenue checkpoints } \\
\text { - } & \text { Compilation of revenue register } \\
\text { Rotation of revenue collectors }\end{array}$ \\
\hline
\end{tabular}

Source: Field data 2014

As the table shows, interestingly, the strategies appear to be similar across the three assemblies except for a few which are peculiar to Tamale Metropolis. These could be attributed to its urban character, which offers relatively greater revenue potential than exists in other districts. The IGF mobilisation 
strategies used by the assemblies corroborate findings by Adesoji and Chike (2013), who identified enforcement by tax personnel, increasing contributions, and awareness-raising among the general public as strategies adopted in Nigeria for effective IGF mobilisation by Federal States.

However, further enquiry and analysis indicated that the strategies employed by the assemblies did not enable them to mobilise enough revenue to undertake development projects. In this regard, the majority $(63 \%)$ of respondents rated the strategies employed by the assemblies as insufficient, citing as reasons assemblies' lack of an effective revenue management system and lack of staff capacity. Responses indicated a view that the available sources of IGF were quite extensive, but were inadequately exploited by the assemblies.

\section{Effectiveness of strategies for IGF mobilisation}

Respondents were asked to assess the effectiveness of strategies used by MMDAs in mobilising revenue for the 2013 fiscal year. As an introductory question, respondents, mainly assembly staff and revenue collectors, were asked whether their assembly set revenue targets or not.

Table 5: Setting of revenue targets by MMDAs

\begin{tabular}{|l|c|c|}
\hline Does your assembly set revenue targets? & Frequency of responses & Percentage of responses \\
\hline Yes & 211 & 76 \\
\hline No & 0 & - \\
\hline Don't know & 68 & 24 \\
\hline Total & $\mathbf{2 7 9}$ & $\mathbf{1 0 0}$ \\
\hline
\end{tabular}

Source: Field data 2014

As Table 5 indicates, the majority $(76 \%)$ of respondents (mostly assembly staff and revenue collectors) said that their assembly sets annual revenue targets. Thus, it would appear that the assemblies do set targets, with planned strategies to achieve the targets, but these are imperfectly communicated to tax payers, as about $24 \%$ of respondents had no knowledge of the taxation process. This indicates that many people, particularly revenue-payers, still do not know much about the collection processes for IGF, although this may include an element of tax dodging.

Table 6 outlines the revenue targets of the three assemblies.

Table 6: 2013 revenue targets of MMDAs

\begin{tabular}{|l|c|}
\hline MMDAs & Revenue targets, GHC \\
\hline Tamale Metropolis & $1,312,390.00$ \\
\hline Yendi Municipality & $6,246,161.00$ \\
\hline Saboba District & $\mathbf{8 4 , 6 1 4 . 5 0}$ \\
\hline Total & $\mathbf{7 , 6 4 3 , \mathbf { 1 6 5 . 5 0 }}$ \\
\hline
\end{tabular}

Source: Composite Budget Document 2014 
As shown in Table 6, Yendi Municipality had the highest IGF target: GH $₫ 6,246,161.00$ (approximately US\$1.5 million at current rates), followed by Tamale Metropolis, and finally Saboba District with the lowest target ( $\mathrm{GH} \not 84,614.50)$. Yendi's revenue target of about $80 \%$ of the total revenue of the three MMDAs may be due to their 2012 IGF performance. The IGF targets were to be achieved using strategies identified by the assemblies. This study sought to establish whether the revenue targets were achieved, with the results shown in Table 7.

Table 7: IGF mobilisation performance of assemblies in 2013 Fiscal Year

\begin{tabular}{|l|c|c|c|c|c|}
\hline Assembly & $\mathbf{2 0 1 3}$ target, $\mathbf{G H} \boldsymbol{\Phi}$ & $\mathbf{2 0 1 3}$ actual, $\mathbf{G H} \Phi$ & Variance, $\mathbf{G H} \Phi$ & Variance, \% & Performance \\
\hline Tamale & $1,312,390.00$ & $521,008.00$ & $791,382.00$ & 60 & Deficit \\
\hline Yendi & $6,246,161.00$ & $992,356.71$ & $5,253,804.29$ & 84 & Deficit \\
\hline Saboba & $84,614.50$ & $26,267.96$ & $58,346.54$ & 69 & Deficit \\
\hline Total & $\mathbf{7 , 6 4 3 , 1 6 5 . 5 0}$ & $\mathbf{1 , 5 3 9 , 6 3 2 . 6 7}$ & $\mathbf{6 , 1 0 3 , 5 3 2 . 8 0}$ & $\mathbf{8 0}$ & Deficit \\
\hline
\end{tabular}

Source: Field data 2014

In spite of the numerous sources of revenue available to the selected assemblies, their fiscal performances were below expectation. Table 7 shows that none of them achieved their revenue targets; rather they were in deficit. This could be attributable mainly to dishonest behaviour by revenue collectors and/or unwillingness of those liable for taxes or rates to pay them, resulting in inadequate mobilisation of IGF. This supports the findings of Osei-Akoto et al. (2007) and AppiahAgyekum et al. (2013) that MMDAs were unable to mobilise the needed revenue internally to finance development projects. Thus despite the abysmal performance of IGF collection by the three MMDAs, Yendi did better than the rest, and were able to mobilise almost twice the revenue of Tamale, possibly because revenue collectors were given bonuses if they met certain revenue targets in a month. Yendi Metropolitan Assembly also used revenue thresholds, and used a special tax force to collect the revenue.

\section{Challenges of mobilising IGF}

Earlier researchers such as Kelly (1995), Boachie-Danquah (1996), King et al. (2003), Nicol (2005) and Agyapong (2012) established a number of challenges confronting MMDAs in effectively mobilising IGF. These included lack of adequate IGF databases, weak monitoring, under-declaration by revenue collectors, corruption, and lack of trained personnel. These challenges are similar to those established by this study (Table 8). 
Table 8. Challenges faced by MMDAs in mobilising IGF

\begin{tabular}{|c|c|}
\hline & Challenges \\
\hline 1. & Inadequate logistics to support effective IGF mobilisation \\
\hline 2. & Under-declaring of revenues by revenue collectors \\
\hline 3. & Inadequate trained revenue collectors \\
\hline 4. & Poor supervision of revenue mobilisation activities \\
\hline 5. & Non-compliance by those liable to pay taxes and charges \\
\hline 6. & Political interference \\
\hline 7. & Inadequate knowledge and skill of revenue collectors \\
\hline 8. & Non-enforcement of by-laws \\
\hline 9. & Poor service delivery by assemblies \\
\hline 10. & $\begin{array}{l}\text { Ineffective collaboration between MMDAs and relevant institutions such as the Town and Country } \\
\text { Planning Department, Land Valuation Board and National Board for Small Scale Industries } \\
\text { (NBSSI) }\end{array}$ \\
\hline 11. & Inefficiency of revenue collectors \\
\hline 12. & Lack of database of taxable properties \\
\hline
\end{tabular}

Source: Field data 2014

\section{Summary}

The paper established that there are various sources from which the studied MMDAs could raise IGF (Table 1). The paper also revealed that the MMDAs under consideration employed various strategies to do this (shown in Table 4). Despite these strategies, however, the assemblies could not meet their revenue targets for the 2013 fiscal year, which suggests that the strategies were not robust or effective.

Furthermore, the study found that the general public was not well informed about the rationale for paying rates and charges, which fuelled a perception among respondents that IGF mobilisation by the assemblies had no impact on local-level development. In this light, about $71 \%$ of tax and rate payers strongly indicated that they did not feel the benefits of any taxes they paid to the assembly and that was why they did not feel any responsibility to pay such taxes. The study nevertheless revealed that a majority (66\%) of respondents acknowledged that the behaviour of those with charge-paying obligations was very poor, suggesting that the problem was deliberate avoidance, rather than ignorance of the need to pay rates or taxes, partly due to their sense that IGF revenues do not translate into local development.

The study also documented a strong perception among the public that there exists corruption in revenue collection processes. This was attributed to poor supervision by the assembly authorities. Finally, the study documented various challenges confronting the assemblies in their efforts to effectively raise revenues (Table 8). 


\section{Conclusion}

Based on the above analysis, it can be concluded that the MMDAs in the Northern Region of Ghana do in principle have access to sources of IGF. However, the assemblies studied cannot meet their annual revenue targets, due to inadequate logistics, under-declaring of revenues by revenue collectors, poor supervision and monitoring, and poor compliance by those residents who are liable for local taxes, rates and charges.

\section{References}

Adesoji, A.A. and Chike, F.O. (2013) The effect of internal revenue generation on infrastructural development: A study of Lagos State Internal Revenue Service. Journal of Educational and Social Research, 3 (2), 419-436. doi: http://dx.doi.org/10.5901/jesr.2013.v3n2p419

Adu-Gyamfi, E. (2014) Effective revenue mobilisation by Districts Assemblies: A case study of Upper Denkyira East Municipal Assembly of Ghana. Public Policy and Administration Review, 2 (1), 97-122. Available at: http://pparnet.com/journals/ppar/Vol_2_No_1_March_2014/7.pdf [accessed 28 November 2015].

Agyapong, F.M. (2012) An evaluation of effectiveness of revenue mobilisation strategies by metropolitan, municipal and district assemblies in Ghana; a case study of Kumasi Metropolitan Assembly. Master's Thesis. Institute of Distance Learning, Kwame Nkrumah University of Science \& Technology, Kumasi.

Alupungu, E., Appia, K.K., Mpeanin, G., Owusu, M.A. and Orgen-Woode, E.B. (2012) Analysing the sources of internally generated funds and its contributions; evidence from Kumasi Metropolitan Assembly. Master's Thesis. Kwame Nkrumah University of Science \& Technology, Kumasi.

Appiah-Agyekum, N.N., Danquah, N.Y. and Sakyi, E.K. (2013) Local government finance in Ghana: Disbursement and utilisation of the MP's share of the District Assemblies Common Fund. Commonwealth Journal of Local Governance, (12), 90-109. doi: http://dx.doi.org/10.5130/cjlg.v12i0.3275

Boachie-Danquah, N.Y. (1996) Mobilisation and management of financial resources for local development: The experiences of Ghana's District Assemblies. The Journal of Management, 2 (13).

Buettner, T. and Wildasin, D.E. (2006) The dynamics of municipal fiscal adjustment. Journal of Public Economics, 90, 1115-1132. doi: http://dx.doi.org/10.1016/j.jpubeco.2005.09.002

Chukwuma, A. (2010) Fiscal federalism, governance and internally generated revenue: Examining weak subnational finances in Nigerian states. International Journal of Business Management and Economic Research, 1 (1), 41-57.

Dick-Sagoe, C. (2012) Performance analysis of internally generated revenue mobilisation in AburaAsebukwamankese District Assembly, Ghana. International Journal of Research in Commerce and Management, 3 (10).

Government of Ghana. (1988) Local Government Law (PNDCL, 207). Accra, Ghana.

Government of Ghana. (1992) The 1992 Constitution. Accra, Ghana Publishing Company.

Government of Ghana. (1993) Local Government Act, Act 462. Accra, Ghana.

Government of Ghana. (2003) Local Government Service Act, Act 656. Accra, Ghana.

Kazentet, H.M. (2011) An assessment of internally generated fund and its contribution for district development expenditure: A case of Asutifi District, Ghana. Master's Thesis. Kwame Nkrumah University of Science and Technology, Kumasi.

Kelly, R. (1995) Property tax reform in Southeast Asia: A comparative analysis of Indonesia, the Philippines and Thailand. Journal of Property Tax Assessment and Administration, 1 (45). 
King, R., Azeem, V.A., Abbey, C., Boateng, S.K. and Mevuta, D. (2003) Financing decentralized development, how well does the DACF work? A pilot tracking of the DACF in four districts. Washington DC: World Bank.

Lutaya, C.N. and West, N.S. (2009) Citizen engagement and local government revenue generation in Uganda. Advanced Project in International Management and Policy. Available at:

http://www.mdpafrica.org.zw/index.php?option=com_content\&view=article\&id=27\&Itemid=30

Neuman, W.L. (1997) Social research methods: Qualitative and quantitative approach. London: Allyn \& Bacon.

Nicol, J.M. (2005) Effective strategies to manage resources of district assemblies. Proceedings at the 14th Biennial Delegate Conference of the Association of Local Government Authorities on 18 ${ }^{\text {th }}$-20th Oct, 2005, Institute for Local Government Studies, Madina, Accra.

Northern Region Co-ordinating Council. (2008/13) Annual report on the activities of the Northern Regional Inspectorate of the Ministry of Local Government and Rural Development. Tamale.

Osei-Akoto, I., Osei, R.D., Quartine, W. and Adiah, G.A. (2007) Public spending at the district level in Ghana. Ghana Strategy Support Programme (GSSP). Background Paper No. 0008. Accra: International Food Policy Research Institute.

Sarantakos, S. (2005) Social research. ( $3^{\text {rd }}$ ed.) Melbourne: Macmillan Education.

Yussif, A. (2012) Assessment of entrepreneurial capabilities of women shea butter processors in Northern Region of Ghana. Master's Thesis. University for Development Studies, Tamale. 